\title{
Redefining a relevant Church Government Model for the Contemporary Church: An Analysis of Church Polity Principles in the New Testament Church
}

\author{
Rev. Dr. Humphreys Frackson Zgambo (Research Fellow NWU) \\ CCAP Blantyre Synod, Malawi \\ Unit for Reformational Theology and Development of the South African Society \\ Internal Box 147 NWU, Potchefstroom \\ North West University, South Africa \\ Email: hzgambo@gmail.com
}

\begin{abstract}
The church government in the New Testament deals with how ecclesiastical authority, operations and order were exercised in the church. The historical and Scriptural principles for church government suggest flexibility in orientation. Evidence for church government from the early New Testament Church is inconclusive. Nowhere in the Scriptures do we find an exclusive picture related to any of the fully/ officially developed systems of church government today. In the New Testament Church, there was no such a thing as highly hierarchical, clerical and ecclesiastical power. The principles of church government for the Supremacy of the reign of Christ in organization and operation characterized the New Testament Church. From a Reformed church perspective, the characteristics of hierarchicalism, clericalism and ecclesiastical power are rejected in entirety.
\end{abstract}

Keywords: Church government, church polity, Reformed church perspective, Hellenism, Judaism, elder, deacon, Presbyterian.

\section{Introduction}

This study explores historical and Scriptural sources to determine how the basic principles of church government were conceived and applied in the New Testament Church for its organization and operations. The New Testament Church followed basic elements of GraecoRoman and Jewish pluralistic systems of government from the ancient first century (Banks, 1993:131ff, Spijker, 1996:424). The question of church polity and church government relates to matters of order, liturgy, service and authority residing within the church structure and in the church's ministry. The purpose of church polity is to study in Scripture how Christ can penetrate into the hearts of his children through the administration of the keys of the Kingdom so that the church truly becomes the body of Christ. Church polity is designed to promote the servitude of the church in the kingdom (Du Plooy, 1997:179f). The aim of this study is to explore from historical sources and the Scriptures how the systems of church government developed, redefine church government concepts and develop a relevant church polity model for the contemporary church in Reformed Church perspectives.

\section{Definition of terms}

The word "government" (noun), is the system of management used to lead, direct, command, and control an organization (Hornby, 2010:649). The study indicates that government composes of a representation of the group of people who are responsible for controlling a state, nation or an organization (Hornby, 2010:649). Haitjema (in Du Plooy, 1982:108ff), holds that in Reformed Church perspective, church polity is the theological science, "sacred science 
of governing the visible church", not merely by a chain of rules and regulations, but constitutes a theological science which studies the rules for the architecture of the church, a building for the people's conduct and existence in the building (Coertzen, 1991:152-166). Heyns and Jonker (1974:16-30) describe church polity as a theological science, a science that studies fundamental principles of the subject as taught in Scripture (ius constituendum), history of the subject and order (ius constitutum) obtained in a specific church. The word, "structure" means the arrangement of and relations between the parts of something complex, the quality of being well organized, or give structure to something (Pearsall, 2002:1423). According to Rensburg (2009:443) the relevant New Testament Greek words for the "elder": episcopos, shepherd or overseer and etymologically related to the word presbuteros, "elder", prosmainoi, care, shepherd (1 Peter 5:1-3, Acts 1:20, 20:28, 1 Timothy 3:1). Therefore, in this study episopos, prosmainoi (episcopal, Episcopalian, shepherd, carer) implies the system of church government under the supervision of bishops or overseers, called "dioceses" while presbuteros (elder, presbyterian, ruler, and carer) is the system of church government under the supervision of plurality of elder, designated "church courts", or "councils".

The central question for the study is: to what extent and how did the concept of office develop in the history and Scriptures, and which principles of church government were applied in the early New Testament Church? The stated questions for investigation are as follows: What are some of the historical perspectives from Graeco-Roman and Jewish systems of government that influenced principles of church government in the New Testament Church? Which concepts of office characterized the organization of the New Testament Church? How did the New Testament Church construct concepts of church government? How could the contemporary church reconstruct and apply new concepts/principles of church government in Reformed church perspective? To assist in the investigation, the following structure is used: historical influences from the Graeco - Roman, historical influences from the Jewish systems of government, historical overview for concept of office in the Scriptures, analysis and evaluation of the principles of the New Testament Church government, reconstruction of the new church polity model for the contemporary church in reformed church perspective, then a summary and conclusion

\section{Historical influences from the Graeco-Roman Government System}

Influences from the culture of Hellenism persisted much longer since the Roman government was deeply impressed by the Greek culture, and even adopted and promoted it to a large extent. The usual view of the Hellenistic era and its culture is that in contrast to the classical era of Greece in the $5^{\text {th }}$ and $4^{\text {th }}$ centuries before Christ (BCE), this was a period in which there were no culturally creative activities (Elwell \& Yarbrough, 1998:195-199). The classical era ended with the advent of Alexander the Great, giving way to the era of the epigonoi (the second generation, the descendants of the Diadochi), until eventually Rome appeared on the scene. It had its own vital force and made important contributions in political, cultural and technical spheres, as well as in the domains of the economy and political government, to which the Romans added their own universal system of government. Any historical atlas of that time shows a worldwide network of economic and cultural links uniting states and nations. Greek historiographers such as Polybius of Megalopolis (203-120 BCE) compiled a history of Rome in 40 books from 220-146 BCE whose 5 books and other fragments collected by Byzantine scholars have survived. Archaeological discoveries in general, all excavations of the Hellenistic and early Roman periods help to a better understanding of the wider world of the New Testament (De Villiers in du Toit, 1998:88).

The Roman Empire was a cosmopolitan entity in which the Hellenistic - Roman culture fully developed unhindered. Everywhere in the eastern and western halves of the Roman Empire, Greek was spoken and understood, since the time of Alexander the Great, it was the common parlance in the Mediterranean area. This Greek, also known as Koine (common), was universally accepted as the language of commerce and international correspondence (De 
Villiers, 1998:139). Everyone sought to master Greek and so be accepted as a Greek, and not doing so was despised "barbarian." The language of the Greeks was spoken not only in Egypt, Palestine and Syria, but also in Rome, Greek culture had first reached Rome through Greek colonialists who had settled in Southern Italy some centuries earlier. The language of the New Testament is also the Koine, the colloquial language of the time, and the inscriptions, the ostraca and papyri which have been discovered have greatly assisted in the understanding of certain expressions and formulations in the New Testament. The Greek Septuagint with its Semitic character, of course, also had an influence on the Greek of the New Testament (De Villiers, 1998:139).

\section{The Graeco - Roman Government System of structure}

Elwell and Yarbrough (1998:195) assert that when Octavian (also known as Augustus Caesar, Luke 2:1) returned in triumph to Rome after the Battle of Actium in $31 \mathrm{BCE}$, he was on the crest of the new wave. In 30-27 BCE, the Roman principate was established and Augustus became the princeps (first citizen) and also the princeps senatus (the first in the Senate), the first to express him in that body. This made the position of Augustus unassailable, so that the year 27 BCE was regarded as the beginning of the Roman Empire, a system of government which would dominate the western scene over next three centuries. The principate was not just a monarchy though the highest authority de facto vested in the emperor as the first citizen. He was formally nominated by the Senate, though after his accession to office he had the most say, however he did not ignore the republican institutions and the will of the people.

Consequently, there was more than a symbolic significance to the acknowledgment by most emperors that their authority, their actual "office" was conferred on them by the will of the people. The principate as an institution of peace and justice was pervaded by a different spirit from that of the earlier eastern and Hellenistic monarchies. The emperor combined several offices in his person: he was commander in chief of the Roman army outside Italy; he had direct control over all the imperial provinces, in fact wherever there were soldiers stationed; he enjoyed legal immunity, and had the right to veto over all laws and every decision taken by officials, while in legal matters he was the highest court of appeal. In addition, he formally held the office of pontifex maximus, high priest (De Villiers \& Pelser, 1998:159-62). The structure of the Roman Empire, there were basically three kinds or groups of people: the Roman citizens, the free inhabitants of the provinces, and the slaves. Roman citizenship had originally been restricted to the citizens of Rome, but in the imperial era, it was extended to include all free citizens in Italy, and later still certain people in the provinces were granted this status (De Villiers \& Pelser, 1998:160-162). A Roman citizen who legally acquired citizenship, enjoyed the following privileges: a right to elect the governing body of the city of Rome, exempt from personal taxes, he could be tried only by Roman courts, he could not be tortured or flogged, nor could be imprisoned without conviction (cf Acts 16:37, 22:25-29). It was illegal to crucify a Roman citizen or to throw him to the wild beasts or to sentence him or her to forced labour. In legal proceedings, a Roman citizen could appeal to the Emperor (Acts 25:11ff). Moreover, Roman citizenship was hereditary (Acts 22:28).

\section{Roman Government Orders}

De Villiers and Pelser, (1998:159-62) hold that after the institution of the principate, an essential prerequisite for any overhaul of the administration was the reorganization of the orders from which officials were to be recruited. In Roman society, there were three orders namely: the Senatorial order: the highest, the repository of the best Roman traditions and the purest Roman blood. Members of the Senate were generally affluent people whose wealth was derived from their estates and from shares in commerce and industry. Though it was formally forbidden for them to engage in business transaction, they got around it by making use of agents, managers, and members of the family who were not themselves senators. Membership of Senate was not hereditary, and so senators, who were all former magistrates, 
had to be elected to the position and automatically became a 'senator for life'. This gave his family and his descendants an advantage above others to be chosen for the position, so the trend developed for certain families to serve as political functionaries for generations. Seeing that all Roman politicians had to be particularly well-off, this prevented ordinary citizens from aspiring to become senators (De Villiers \& Pelser, 1998:159-62). The Equestrian Order: originally comprised people who had made a horse available to the authorities in the case of war. Besides being free born, members of the order had to be people of some means. Because they could carry out monetary transactions, these men made up the financial aristocracy in Roman society. Foremost offices in the equestrian career were those of tribunus militum (a knight), praefectus (commander) and procurator (deputy, administrator) which extended from the financial administration of a province to independent control of it. In contrast to the senatorial officer, the equestrians usually remained in the same office for many years. Consequently they were on average older officials, more conversant with administrative matters. The plebeian order comprised people with such professions as tutor, orator, physician, merchant, manual worker and farmer who inter alia tilled the lands (Pelser, 1998:159-62).

\section{Roman Government Provincial Administration}

According to Du Toit (1998:216ff), the administration of the provinces, in the empire there were two categories of provinces: senatorial and imperial. Senatorial Order: Senatorial provinces were those where peace prevailed and which gave no problems was controlled by the Senate. At the head of such a province was a proconsul (a former consul) or propraetor (former praetor) with the title proconsul. Unlike the imperial provinces, the senatorial provinces had a civil government. There were no military units stationed in them. The proconsul held the ius glaii (the power to impose the death penalty and carry out execution), but this could be set aside if an appeal to the emperor was successful. Asia was the most important senatorial province, with Macedonia and Achaia close seconds (Du Toit, 1998:216ff).

Imperial provinces: along the frontiers of the empire, as well as those which were not easily subjected and thus were difficult to rule, were placed under the emperor's control, and were known as imperial provinces. In such a province the emperor was represented by a legatus Augustii pro praetor (a general delegated by the emperor), which meant that it was under military government. That official was also invested with the ius gadii. Over provinces of lesser status a praefectus or procurator was appointed. After 6 AD this was the status of the province of Judea, which now fell under the jurisdiction of the legate of Syria. In order to prevent officials from exploiting the provinces, they were paid a fixed salary (De Villiers \& Pelser 1998:159163). In this way, the particular shape of Graeco-Roman civilization was established in plural society which along with Christianity became the foundation for Western civilization (De Villiers, 1998:88).

\section{Historical influences from the Jewish System of Government}

Du Toit (1998:216ff) argues that the Jewish world milieu of the New Testament was influenced by Persia, Rome and the Diaspora by adopting some of their pluralistic facets. Judaism could be categorized as Judaism inside Palestine and that beyond its border known as the Judaism of the Diaspora (dispersion, scattering) or Hellenistic Judaism. The Jewish communities, in minority that time dispersed over large sections of the Roman Empire, were more strongly exposed to Hellenising influences than those in Palestine (Du Toit, 1998:216). Judaism itself did not present a uniform picture in other places; conversely, the pluralistic nature of Judaism of the New Testament must not be exaggerated, as if the existence of varying Judaism represented completely different milieus. Dunn (1977:236-37) holds that "Hellenistic Christianity" embraced the whole of first century Christianity since more or less all of Palestine and all Jewish life and thought was to greater or less degree influenced by Hellenism. Despite their variations, the respective 'Judaism' including that of the Diaspora, possessed a religio- 
ethical and national bond which distinguished the Jews from all other nations, thus justifying the use of the term 'Judaism'.

There can be no denying that there were many influences which acted upon Judaism such as Hellenism and eastern syncretism. For one thing, its degree of the essence of faith, belief in the One, invisible, living God, remained intact and unaffected. Furthermore, though it was variously interpreted, the concepts of the Torah, covenant motif and shared future expectation of a dawning Kingdom of God or of a Messianic utopia, bound all Jews together (Du Toit, 1998:217).

Elwell and Yarbrough (1998:66) assert that the most significant unifying factors for the Jews were their relationship to God and their sense of uniqueness in world history. Other factors that unified the Jews were: the idea that God had placed them in Palestine forever; the Messianic fervour of the time; the synagogue; the Torah and tradition, which included Sabbath keeping and circumcision; the temple; the priesthood; and the festivals; these along with their sacred scriptures served as definite identity markers (Elwell \& Yarbrough, 1998:66). Moreover, the Jewish life-style, viewed as a whole, was typified by a quality (ethos) far higher than that of their pagan neighbours. Of central important also, as unifying factors, were Jerusalem and its temple constructed by Solomon. The Palestinian Judaism of the first century CE cannot be understood apart from the 500 years or so of Jewish history beginning with the Persian period.

Many Old Testament strands run through to the New Testament via the Judaism of that time. However, in addition to the ways in which the religion of Israel and of the Old Testament continued and was adapted in early Judaism, there were other developments in this era which placed their particular stamp on the Jewish world of that time and had a great influence on the first early Christians (Elwell \& Yarbrough, 1998:65-66). Anyone who chooses to ignore the Inter-Testamental period forfeits a significant tool for understanding the New Testament. Sources for study of Palestinian early Judaism in and around the New Testament era are literary sources from Jewish writings, the latest Old Testament books of Haggai, Zechariah, Malachi, the writings such as $1 \& 2$ Chronicles, Ezra, Nehemiah, Ecclesiastes and Daniel, the Jewish historian Flavius Josephus is our richest source regarding Jewish history, religion and national life in the last two centuries BC and the major part of the first century CE (Du Toit, 1998:217).

Additionally, the Old Testament Apocrypha and Pseudepigrapha, the Qumran literature and the rabbinic literature are some sources of early Judaism (Du Toit, 1998:220). The Greek and Roman writers such as Polybius, Diodorus, Strabo, Dioo Cassius, Tacitus and Suetonius do offer useful details concerning events in and around Palestine in the Seleucid and Roman periods BCE - CE . From these sources we learn that the destiny of the people of Palestine was very closely influenced and interwoven with diversity within the history of their environment (Du Toit, 1998:220). After the fall of Archelaus in CE 6, the government structure of Judaea together with Samaria and Idumaea (Edom) comprised one such lesser province and was administered independently, though in special circumstances, it fell under the control of the legate of Syria. Initially, the Roman governor of Judaea had the title of prefect, but during the reign of Claudius this was changed to procurator. The Roman governor had his headquarters in Caesarea, travelling up to Jerusalem only at the time of important festivals. There, in all probability, his official residence or praetorium was the palace of Herod, an impressive stronghold in the western part of the city where troops accompanying him could also be quartered (Mark 15:16, cf Matthew 27:27).

In the New Testament period, five infantry cohorts (each 500 to 1000 men) and one cavalry division of the same strength were stationed in Judaea (Pelser, 1998:257). The governor was also the highest juridical authority in the country, though he did not always make use of his powers for the Romans allowed the various indigenous nations a good deal of latitude in 
conducting legal matters to local traditions. Thus the prefects and procurators of Judaea left much of the civil and criminal administration of justice to the Sanhedrin (Pelser, 1998:257).

\section{The Sanhedrin System of Government Structure}

The Sanhedrin Government structure: the name "Sanhedrin" is a Hebrew transliteration of the Greek work "sunedrion" meaning "council." Its origin is shrouded in uncertainty. Jewish traditions carry it back to the government advisory body of seventy leading figures appointed to assist Moses in administration (Numbers 11:10-24), which would be reconstituted by Ezra after the exile. The body in the post-exilic came to be an assembly of prominent aristocrats of Israel. During the Seleucid regime, the Sanhedrin appeared as convocation of the "elders" (heads of families- Greek: gerousia). According to Josephus the Historian, it was proclaimed as such by Antiochus in 198 BC (Antiq x11:138-44 in Pelser, 1998:257).

In the Maccabaean period (165 BCE), there is mention of the two governing groups of dignitaries: the archontes (rulers) and the elders. Presumably, the "elders" were officials with special functions and the elders were the heads of the leading aristocratic families. Under the earlier Hasmonaeans in Palestine, this body continued to enjoy respect, but it fell into disfavour with the later members of that house, forfeiting much of its significance. Herod 1 forced the two groups of leading Jews, the priestly aristocracy and the heads of families, into the background. As for the Sanhedrin, he had several of its prominent members put to death, while he deprived it of its jurisdiction and turned it into a puppet he could manipulate in his own legal processes in Jewish society (Pelser, 1998:258-9). The Romans, however, considerably restored the power of the Sanhedrin government by transferring partial jurisdiction to it and allowing it to function as a kind of legislature for internal political matters, which had not previously been the case. This enabled the Sanhedrin to feature as the Jews' Parliament, Government (Executive authority) and Supreme Court of justice. But it was only in Judaea that it had any formal authority, though its prestige extended to the whole Jewry as such. Besides with the high priest as its president, in the time of Jesus and the Apostles, the Sanhedrin in all probability consisted of the seventy members (following Numbers 11:16), composed of three groups: the "chief priests" (the most prominent members of the priestly aristocracy Mark 14:53, 15:1 Acts 4:5), the elders (heads of families), and the scribes (mostly Pharisees).

The function of the Sanhedrin was among others were to act as a plenary session which occurred only seldom, seeing that most matters were dealt with by smaller committees or councils (Pelser, 1998:261). There were occasions when a full sitting was required in cases of capital crimes and apostasy (heretical teachers, seducers, false prophets, rebel sons, adultery and many more). The Sanhedrin was located in Jerusalem as the highest authority, not only the body of its kind in the Jewish domains. Across the country, there were also many local governing bodies or 'Sanhedrins', smaller councils as recorded in the New Testament (Mark 13:9, Matthew 5:22, Pelser, 1998:261).

\section{Historical overview for concept of office in the Scriptures}

Burtchaell (1992:25ff) contends that the concept of "office of an elder" originated in the Old Testament. Historically, the office of an elder was first established in the days of Moses to share the burden of leadership (Numbers 11:17). It is therefore difficult to talk about the "office of the elder" in the New Testament without reflecting on its original context from the Old Testament.

\section{The Original Understanding for Office}


Old Testament Israel was a patriarchal society, as were most Middle Eastern societies and in fact many remain so up to the present time. Respect and deference were shown to older men. Wisdom gained through long life experience was honoured. An inherent authority was concomitant with being an elder of the household, village, or tribe. After the Lord God appeared to Moses in the burning bush, he instructed Moses to gather the elders of Israel together to inform them he was about to deliver Israel from Egyptian bondage and lead them into the Promised Land (Exodus 3:16-4:29). The elders were to go with Moses to represent the people of Israel in their cause before Pharaoh Rameses 2 (1290-1224 BCE). After giving Moses the law, the Lord instructed him to bring seventy elders to the base of the mountain (Mt. Sinai) that they might worship the Lord in confirmation of the covenant (Exodus 20-23, 24:1-11). Later the patriarchal cultural tradition was elevated to a "spiritual office". When Moses had led the people of Israel out of bondage in Egypt and they had begun their second year of sojourn in the wilderness, he became overwhelmed with the burden of leadership. Though the Lord had led the people through the Red Sea on dry land and had miraculously provided them with water and manna, they had grown discontent and longed to return to Egypt (Numbers 11:4-6f). Dismayed by the people's fickleness and ingratitude, Moses cried to the Lord:

I am not able to carry this entire people alone; the burden is too heavy for me. If you will treat me like this, kill me once, if I find favour in your sight, that I may not see my wretchedness (Numbers 11:14-15)

The Lord did not grant Moses' petition, but instead instituted a system of shared spiritual leadership through "a number of elders" (Burtchaell 1992:33f). He instructed Moses to gather seventy men from the elders of Israel who were recognized and proven leaders. He then demonstrated his approval of the elders by sending His Spirit upon them (vv 16-17, 24-25). This visitation of the Holy Spirit served as evidence of God's hand being on them and was, in a sense, their ordination. God earlier had shown his favour to the Levites and Aaronic priests in their ordination (Numbers 8, Leviticus 8). It must be conceived therefore that the purpose of plurality of elders was that spiritual leadership be a shared leadership. The second generation shared in Moses' authority to command the people of God (Deuteronomy 27:1). Joshua continued the practice of shared spiritual leadership through the elders (Joshua 8:10).

Burtchaell (1992:35ff) continues to argue that although the office of elder as spiritual leader was instituted in the days of Moses over 1,400 years before Christ, it did not blossom until the inauguration of the synagogue system in the sixth Century BCE. After the Babylonians destroyed the temple in Jerusalem in 586 BCE and deported the people of Judah, the exiles began to gather for the reading of Scripture, worship, the exposition of Scripture and prayer. The exilic prophets such as Jeremiah (Jeremiah 29:1) and Ezekiel (Ezekiel 8:1, 14:1, 20:1) referred to elders as leaders among the people of God during that time. With the spread of the Synagogue system, the prominence of elders grew. After the return from the Babylonian captivity, the rebuilding of the temple under Zerubbabel, and the resulting reinstitution of the Leviticus sacrificial system, synagogues continued to be established wherever Jews went in the Mediterranean world, and the rabbis (teachers) and elders grew in prominence (Taylor in Cowan, 2004:78f).

\section{Office in the New Testament Church}

Brand and Norman (2004:11-19) holds that in the New Testament, God gives certain persons as gifts to the congregation as a 'shepherd and minister'. The shepherds guard the flock, for the congregation is the flock of God (Acts 20:28). Within the early church an elder was a person with the responsibility to rule with regard to religious - ethical matters and had to provide guidance. An elder had to lead and help the congregation that was entrusted to him like a shepherd to his flock (Rensburg, 2009:443ff). The basic meaning of presbuteroi are "elders" with the emphasis on the "ripeness of judgment" rather than just on "age," and gives 
the translational responsibility as "a group of elders" (Acts 22:5, 1 Timothy 4:14). In the New Testament again there was no set pattern for selection and appointment of church officers. Some early church leaders were appointed by God directly and the church was notified of the choice through inspired prophets for example in cases of Paul and Barnabas (Acts 13:1-3); possibly Timothy (1 Timothy 1:18, 4:14). Here the joint actions of appointment by the Holy Spirit and congregations in other places (Acts 6:1-6, 13:1-3, 15:22-28) leave open the possibility that men chose in some way but with the approval of the Holy Spirit could be described as placed in the church by the Holy Spirit (Ferguson, 1988:322, 311).

Vorster (2011:14-20) holds that many scholars in ecclesiastical church polity discourse unanimously agree that the New Testament does not prescribe a fixed system of government, officers and titles. It only gives basic principles of church government which should be applied in the structuring of churches and a clear description of the mission of the church which should be served by the structure established according to given situation. Brand and Norman (2004:4-5) argue that the issue of governance of the church is mostly visibly seen in the Lordship of Christ. The church exists by and under His Lordship. He builds the church and calls it "my church" (Matthew 28:18). Christ instructs the church that its task is to observe all that He has instructed. The governance of the church is also manifested in the quest of believers to conform their ministries and relationships to the teaching of the Word of God (Brand \& Norman, 2004:4-5). Christ's Lordship and authority are evidenced in that He appoints officers who minister within the church and gives gifts for ministry to the church (Ephesians 4:7-12, 1 Corinthians 12:5-6).

\section{The Concept for Office in Reformed View}

Janssen (2000:5) argues that the Reformed tradition church polity finds in Scripture a basis on its foundation for understanding of "offices" and "assemblies of the church." The concept of "office" is central to an understanding of Reformed church polity in Reformed perspective, and thus finds its roots in German amt. In its origins, amt reflects a feudal context in which the vassal was required to serve his lord. He was obliged to serve. Vorster (2011:17) holds that God calls officers to serve in the various ministries. In the "calling" three parties are involved: Christ who calls, the officer who is called, and the congregation who acknowledges the "calling" (Spoelstra in Vorster, 2011:17). Milne (1982:224) holds that the early church was committed to service, a further means of bringing glory to God.

\section{Different Types of Offices in the Church}

There are four different types of offices in the church namely: ministers of the Word, doctors or professors of theology, elders and deacons (Vorster, 2011:15). Vorster (2011:15) asserts that offices are instruments in the hands of Christ through which He institutes, conserves and builds the church. Christ uses different people in different ministries for this purpose. The office bearers are "servants" who primarily receive their mandate to serve from Christ. They are the organs of Christ (Bouwman in Vorster, 2011:15). The one who holds in the church "office" stands under obligation to serve the Lord Jesus Christ, the Head of the church (Janssen, 2000:17).

\section{Office of the Pastor}

In Geneva, Switzerland, Calvin influenced by Bucer in 1539 - 1541 in his famous "Institutes" on Ordonnances Ecclessiastiques, organised the churches into a fourfold- ministry of pastors, elders, doctors (teachers) and deacons, though he tended to conflate the office of teacher with that of pastor. The pastor shepherds the flock through ministration of the Word, pastoral care, Sacraments and the maintenance of church discipline which are necessary for the well- being of the true church of God. The church in the world is a struggling church and needs comfort and admonishment. The church must fulfil its calling in an orderly and fundamental fashion (Bouwman in Vorster, 2011:16). The pastor of each church along with one or more of the 
elders served on a body known as the Consistory, a body which had the responsibility to establish the Confession of faith and other tools for teaching and propagating the faith and which also served as the final court of church discipline in Geneva (Brand \& Norman, 2004:18). Henderson (1962:58) points out that in 1541 Calvin insisted in the holistic pastoral office as:

\begin{abstract}
Being limited to ministration in the Word of God, all their wisdom to the understanding of that Word, and all their eloquence in the preaching of it. If they wish to decline, they are false in their sentiments, ambiguous in their language, traitors and infidels in all their office, whether they be prophets, bishops, doctors, or be established in a greater dignity.
\end{abstract}

Brand and Norman (2004:18) again hold that John Calvin, the father of Reformed tradition in Geneva in Ordonnances Ecclessiastiques in 1541 describes a brief analysis of the fourfold pattern of offices of church ministry namely: pastors for the ministry of Word and sacraments, doctors (doctorum munus), for training of students for ministry in universities, elders for supervision and government of the church, and deacons for caring the sick and welfare of the vulnerable in the Actc of the National Synod of Gravenhage (1586, Henderson, 1962:58). Calvin argued that the office of pastor was to be considered the ordinary office of the church in perpetuity, while the offices of apostle, prophet, and evangelist were for the early church alone. He criticized the Western episcopacy because of its neglect of its primary duties and because it arose out of a faulty understanding of Scriptures (Brand \& Norman, 2004:18). Calvin influenced to a large extent the development of Reformed Church polity in France, Netherlands, Switzerland, Hungary, England, Scotland, and later also in South Africa, United States of America and Canada (Vorster, 2011:3-4).

\title{
Office of the Doctor (doctorum munus)
}

The church order indicated, by implication that the office of doctor (teacher) was that of professor in theology and stated that the office was "to explicate the Holy Scripture and to stand for doctrine against heresies and wrongdoers." Henderson (1962:30-31) holds that the office of doctor (teacher) and the office of prophet under the gospel were clearly linked and Calvin never succeeded in drawing a completely clear line of distinction between them. The distinction he draws between prophets and doctors lay in the area of the intensity of the exercise of their didactic function. The gospel prophet had a slightly wider range of responsibility to make known "the will of God by applying with dexterity and skill prophecies, threats, promises and the whole doctrine of the Scripture, to the present use of the church;" while the office of doctors (doctorum munus) "consists in taking care that sound doctrine be maintained and propagated in order that the purity of religion may be kept in the church." For Calvin, "all pastors ought to be doctors, but functionally and by office all doctors are not pastors" (Henderson, 1962:31).

\section{Office of an Elder (presbuteros)}

Du Plooy (1998:5ff) holds that after extra- ordinary services done by the apostles and prophets, such as laying the foundations of the church in and through Christ, special services of the elders were instructors and governors. The New Testament Church was responsible to confirm those who have the gifts and skills for leadership. The elders were appointed and had to fulfil their duties as God expected (Acts 14:23, Titus 1:5, 1 Peter 5:2). The calling of leaders required both spiritual and social processes. Elders were edified by the word and it gave them the governing authority and divine inheritance. Christ is the great Shepherd of his herd (Acts 20:32, Hebrews 13:20, 1 Peter 2:25). Other leaders were identified, recruited, trained and tested those who might serve as additional leaders (2 Corinthians 8:22). The whole community confirmed those who have been selected (Gelder, 2000:182). The fruit required was mostly social in character in the sense that these behaviours function primarily in relationship to other persons. To be a leader in the church, a person must demonstrate the ability to develop mature 
relationships with other believers and this applied also to women such as Mary Magdalene (Nicolaides, 2018).

Brand and Norman (2004:18) repeatedly hold that Calvin argued against episcopacy, that there is only one level of ordained ministry (the elder), not two (elder and bishop), and there are two kinds of elders in the New Testament namely 'teaching and ruling elders', a conviction that arose from his interpretation of 1 Timothy $5: 17$. Since the elders of each congregation were chosen by the church and then sent on to serve in the Consistory, this model of governance was significantly different from earlier episcopal forms, though it did still provide for certain amount of top-down authority. John Knox (died 1572 CE), one of Calvin's associates in Geneva and a Marian exile, later introduced this model to like-minded ministers in Scotland, and in 1592 CE, due to largely efforts of Andrew Melville (died 1622), and the Kirk of Scotland became officially Presbyterian (Brand \& Norman, 2004:18). According to Henderson (1962:110-111), most Reformed traditional churches follow the re-edited Calvin's fourfold ministry of pastor, doctor, elder and deacon - church order of Synod at Dort in 1519, 1539 CE, then Synod at Emden (later Synods of 1578 CE, 1581 CE, 1586 CE), without too much questions. Any particular office emerges out of the understanding of priesthood of all believers. There can be no "hierarchical relation" between believers and the particular office because God's ministry resides in and among believers themselves (Janssen, 2006:9).

\section{Office of the Deacon}

While the "office of elder" as a representative leader originated from the Old Testament, the office of deacon originated in the New Testament, as Luke recorded in Acts 6. Janssen (2006:202) asserts that the office of the deacon centres on help or mercy and righteousness. With the rapid growth of the New Testament Church, the scriptures indicate that the early church faced a number of ethnic problems. The Apostles introduced a church order system of diakonos form of governing the ethnically divided church in the New Testament Church for the sake of church order and relevance. Originally a diakonos was a servant who waited at table. This concept is never far from the surface when the word and its cognate's diakoneo and diakonia are used in the New Testament (Williams, 1972:118-119). Grudem (1994:918) argues that the word "deacon" is a translation of the Greek word diakonos which is the ordinary word for a male "servant" when it is used in contexts not dealing with church officers. Deacons are mentioned clearly in Philippians 1:1: "To all the saints in Christ Jesus who are at Philippi, with the bishops and deacons". In fact there were also times when even women could serve as a deaconess in the early church (Nicolaides, 2006).

Therefore, in the New Testament Church, the Apostles exhorted the church to choose seven men of good reputation, full of wisdom and Holy Spirit, to oversee this ministry. The church chose seven, all of whom had Greek names (v 5) and the Apostles ordained them (v 6). One of the seven men, Stephen became the first Christian martyr (Acts 7). Another, Phillip was also a gifted evangelist who evangelized Samaria and many other places. As time passed, deacons took on other mercy ministries such as providing food and clothing to prisoners, providing shelter for the homeless and job training in honourable occupations for new converts among former thieves, prostitutes and gladiators (Wedderburn, 2004:44-45f).

In the New Testament Church principle of government, deacons were appointed to provide relief resources to the vulnerable, widows, orphans and the sick (Acts 6:1-10, James 2:25ff, 5:13-16). At Philippi and in the Asian congregations to which the Pastoral letters were written, there were "overseers" and "deacons" (Philippians 1:1, 1Timothy 3:1-13, Titus 1:5-9). The Apostles urged the church deacons to take the responsibility of caring for the vulnerable and the poor. Janssen (2006:202) argues that the deacon "enters the world fully in the needs of families and the society. He is completely active in the ultimate goal of all, the social ideal". The deacon embodies the truth that the apostolic activity of the church is not exhausted in preaching and home visitation. In fact, the deacon stands closer to God's Kingdom intentions 
than does the elder, and so embodies the theological reality that the salvation one experiences through the mediation of the church is only a means to the grater goal. The deacon is, in fact, closer to "the real goal, the kingdom of glory". The deaconate does its work "with its face to the world." It is the deacon who sees the burning vision of the Kingdom of God on earth (Janssen, 2006:203).

Grudem (1994:912) argues that there was quite a consistent "council of elders" system as the main governing authority which executed discipline to the lapsed members in the New Testament churches. Nowhere do we have a single, hierarchical or dictatorial leadership system executing discipline within the church community. Scripture indicate that Paul's normal procedure from the time of his first missionary journey was to establish a "council of elders" for the sake of shared governance and discipline in each church shortly after the church began.

\section{Analysis and evaluation for the basic principles of church government in the New Testament Church}

In light of the discussion above, the study will analyze and evaluate the historical and Scriptural sources and reconstruct a relevant church government model for the contemporary church in a Reformed Church perspective as follows:

\section{From the historical sources of Graeco-Roman Government}

The Hellenistic culture influenced the New Testament Church Government. Some forms of Hellenistic culture persisted much longer in the government of the New Testament Church. Since the Graeco-Roman government was deeply impressed by the Greek culture, they adopted and promoted it to a large extent in the government of the early New Testament Church. The Graeco-Roman Empire was a cosmopolitan entity in which the HellenisticRoman culture fully developed unhindered. "Hellenistic Christianity" embraced the whole of first century Christianity since more or less all of Palestine and all Jewish life and thought was to greater or less degree influenced by Hellenism (Dunn, 1977: 236-37). Therefore, Hellenistic culture greatly influenced the formation of the New Testament Church Government. This is not surprising given the extent to which the Greeks had infiltrated the ethos of other societies and cultures and their language was in an event the lingua franca.

\section{Latin and Greek Languages}

The Latin and Greek languages and culture no doubt influenced the New Testament Church. Latin and Greek languages became the only civilized means of communication in the early New Testament Church. Everyone sought to master Greek and so be accepted as a Greek, and by not doing so, one was despised as being a "barbarian." Everywhere in the eastern and western halves of the Roman Empire, Greek was spoken and understood, since the time of Alexander the Great, it was the common parlance in the Mediterranean area. This Greek, also known as Koine (common), was universally accepted as the language of commerce and international correspondence. Therefore, Latin and especially the Greek language and culture greatly influenced the formation of the systems of the New Testament Church in which some of the early Church Fathers operated.

\section{Roman Government Orders}

The Roman Government orders including the institution of the principate, influenced the organization of the New Testament Church, and the reorganization of the orders from which officials were to be recruited namely: The Senatorial order: the highest, the repository of the best Roman traditions and the purest Roman blood (De Villiers \& Pelser, 1998:159-62), the Equestrian Order, the equestrian career driven individuals were those of tribunus militum (a knight), praefectus (commander) and procurator (deputy, administrator), the plebeian order 
comprised people with such professions as tutor, orator, physician, merchant, manual worker and farmer (Pelser, 1998:159-62). Therefore, it is evident that the Roman Government orders greatly influenced the organization of the systems of the New Testament Church.

\section{Administration}

The administration of the provinces influenced the organization of the New Testament Church such as senatorial imperialism. Senatorial Orders and Senatorial provinces promoted the prevalence and maintenance of peace and order. At the head of such a province was a proconsul (a former consul) or propraetor (former praetor) with the title of proconsul, the senatorial provinces had a civil government. Therefore, the administration of the provinces influenced the organization of the system of the New Testament Church. The church administration sets up its rules and regulations to help it to operate to its maximum potential under the given Roman instructions.

\section{From historical sources of the Jewish System of Government}

Judaism influenced the New Testament Church. Jewish systems of government impacted strongly on the principle of plurality of elders to exercise authority in the New Testament Church. Judaist tradition influenced the New Testament Church. Judaism represented different milieus of Christianity and thus it also greatly influenced the formation of the New Testament Church.

\section{Messianic Fervour}

Messianic fervour influenced the New Testament Church. Messianic fervour of the time included the synagogue, the Torah and tradition, which included Sabbath-keeping and circumcision, the temple, the priesthood, and the festivals- these along with their sacred scriptures served as definite identity markers (Elwell \& Yarbrough, 1998:66). Moreover, the Jewish lifestyle, viewed as a whole, was typified by a quality (ethos) far higher than that of their pagan neighbours (Pelser, 1998:249-256f). Therefore, the Messianic fervour also tended to influence the formation of the New Testament Church.

\section{The Sanhedrin System of Government Structure}

The Sanhedrin System of Government structure influenced the New Testament Church. The name "Sanhedrin" is a Hebrew transliteration of the Greek work "sunedrion" meaning "council." Its origin is shrouded in uncertainty. Jewish traditions carry it back to the government advisory body of seventy leading figures appointed to assist Moses in administration (Numbers 11:1024), which would be reconstituted by Ezra after the exile. The body in the post-exilic came to be an assembly of prominent aristocrats of Israel. During the Seleucid regime, the Sanhedrin appeared as convocation of the "elders" (heads of families- Greek: gerousia). According to Josephus the Historian, it was proclaimed as such by Antiochus in 198 BC (Antiq x11:138-44 in Pelser, 1998:257). This Sanhedrin System of Government structure also influenced the formation of the New Testament Church as well.

\section{From concept of office in the Scriptures}

\section{Supremacy of Christ characterised the New Testament Church.}

The principle of church government for the supremacy of Christ characterised the New Testament Church. Christ is the King of the Kingdom of God and Head of the people of God, the church (Matthew 16:18, 1 Corinthians 15:24-28, Ephesians 1:22) Christ is the Head of the church and source of all its authority (Nicolaides, 2010). In essence, the Kingdom of God is about the reign of God through Christ in the very conscience of the life of the church. Christ supremely reigns differently in all respects from earthly kings. All believers in Christ are 
unconditionally bound to obey the Word of the King. As Christ is the only sovereign Ruler of the church, His Word is the only word that is law in the absolute sense.

Vorster (2011:8-10) holds that the Kingdom of God is indeed the central aspect in Biblical revelation. The primary idea of the Kingdom of God in Scripture is that of the rule of God established and acknowledged in the hearts of sinners by the powerful regenerating influence of the Holy Spirit, insuring them of the inestimable blessings of salvation. This rule is realized on earth, but will not reach its culmination until the visible and glorious return of Jesus Christ (Berkhof, 1969:568). The present realization of Kingdom reign is spiritual and invisible, to deliver all people from the slavery of sin. This reign has already been manifested in the coming of Christ, but will be revealed in its completeness at the end of time. The reign of God is simultaneously a present and future reality (Ridderbos, 1975:343f).

According to the Reformed Church perspective, legitimate church polity must be characterized on the conviction of the Sovereignty of God, Christ as Head and Ruler and must be fundamental to understand the context of the New Testament Church (Koffeman \& Smit, 2014:40). The Scriptures never refers to a human being as a "head of the church" as claimed by the Roman Catholic Church or Episcopal Church view. This title exclusively belongs to Jesus Christ alone. He is the only Head of each local assembly. The church has no head on its own (Viola, 2008: 295). In the Reformed tradition, there is no such a thing as hierarchical and ecclesiastical power. A notion of personal hierarchy is structurally avoided (Janssen, 2000:15f). Therefore, the principle of church government for the supremacy of Christ characterized the formation of the New Testament Church.

\section{The Principle of Government by the presbuteroi Elders}

The principle of government ruled by the presbuteroi' (elders') characterized the New Testament Church. Du Toit (1998:257) holds that during the Seleucid regime, the Sanhedrin appeared as a convocation of the spiritual elders (heads of families -Greek gerousia) representing the nation (Du Toit, 1998:257). The Jewish synagogue had a presbytery (Banks, 1993:131ff, Spijker, 1996:424. It appears that in each of them, large board elected from its midst bishops - official supervisors with much authority; and deacons - servants who carried out orders (Smith, 1976:15-16).

The New Testament Scriptures suggest a flexible evolving administrative format of church polity and order starting with the twelve Apostles in the early chapters of Acts moving to a delegation of responsibility of deacons in Acts chapter 6, and later to a more complex system of official council in Acts 15 and 20. The New Testament Church continued the practice of accepting "elders" as spiritual leaders, a practice obviously endorsed by Christ's own Apostles. The death of the Apostle James in about 44 CE (Acts 12:2) was a catalytic factor that marked a transition in the Jerusalem Church. Up to that point the church there had been under the direct spiritual leadership of the Apostles who had remained even after the stoning of Stephen around CE 35. About the time of the persecution by Herod Agrippa 1 (James execution), Luke's record begins to regularly mention "elders" in the Jerusalem Church. Barnabas and Saul delivered the famine relief offering from the Gentile Churches to the "elders" of Jerusalem (Acts 11:30). Therefore, the principle of government ruled by the presbuteroi' (elders') characterized the New Testament Church.

\section{The Principle of Priesthood of Believers in the Church}

The principle of priesthood of all believers characterized the New Testament Church. In the Old Testament times people did not approach God directly. A priest acted as intermediary between God and sinful man. With Christ's death on the cross, resurrection and ascension to the right hand of the Father, everything changed. Now people can come directly into God's presence without fear (Hebrews 4:16) and are given responsibility of bringing others to him also (2 Corinthians 5:18-21. The members of the church are prophets, priests and kings under 
Christ, so that appointed leaders should be attentive to listen to what members hear from God, as the church together seeks to discern God's will to do it. 1 Peter 2:9:

\author{
But, you are a chosen generation, a royal priesthood, a holy nation, and His \\ own special people that you may proclaim the praises of Him who called you \\ out of darkness into His marvellous light.
}

When people are unified with Christ as members of his body, they join in his priestly work of reconciling God and man. Hunter (1950:304) holds that Calvinism taught the sense of personal worth and human dignity principally because John Calvin was an outright uncompromising exponent of essential democracy in church and state. The principle of the sovereignty of the people is the gift of Calvinism to the contemporary world. Each one is given at least one spiritual gift and will be held responsible for their faithful use of it for the benefit of others. No one in the church is excluded from having to use their spiritual gifts to serve others (Hunter, 1950:304). The church is a "body" where everyone contributes (1 Corinthians 12:1-26, Romans 12:3-8). Individual Christians have received a delegated ministry by means of their relationship with Christ, membership of the church, participation in the Word and sacrament. Therefore, the principle of priesthood of all believers characterized the New Testament Church.

\title{
The Principle of Servant-leadership in the Church
}

The principle of servant-leadership characterized the New Testament Church. A powerful example of Christian leadership is where authority is based on neither service nor power. Jesus Christ is quoted in Mark 10:44-45 as saying:

\begin{abstract}
For whoever will be the greatest shall be the servant of all. For even the son of man came not to be served but to serve and give his life as a ransom for many people (Mark 10:44-45).
\end{abstract}

In Christ's Kingdom, service is the way to go ahead to greatness. The desire to be on top will hinder, not help. Rather than seeking to have one's needs met, one needs to look for ways to minister to the needs of others. True greatness comes in serving others (1 Peter 5:1-4). The function of biblical leaders is not to do the work exclusively, but to provide a model and serve for example in the areas such as philanthropy and corporate social responsibility (Nicolaides, 2017), and also to train and lead the members in the exercise of their own gifts for the church to grow (Wagner, 1976:63f). This is explicit in the purpose of the Spirit's gifting, which is for the common good (1 Corinthians 12:7). In the church, leaders must show humility and take the example of Christ. Leaders are therefore esteemed, not because of their office but because of their work (Hunter, 1950:304ff). Therefore, the principle of servant-leadership characterized the New Testament Church.

\section{The Principle of Ecumenical Ecclesiastical Connectionism}

The principle of ecumenical ecclesiastical connectionism characterized the New Testament Church during times of crisis (Acts 8:1-8, Brand \& Norman, 2004:112-113). In Acts 1-4, it was persecution which forced the Christians out of Jerusalem and drove them into Judaea and Samaria. The persecution also helped spread the gospel of God and in a sense brought great results from the believers suffering. In Scripture, it is recorded: "the entire community of believers in one locale" (Acts 8:1), "the entire community of believers connected with joy to several regions" to hear a report from Paul and enjoy relative peace (Acts 9:31). The elders represented from several congregations conferred on doctrine at Jerusalem (Acts 11:22, 18:22). Elders met to represent several congregations on issues such as dietary laws and circumcision at Antioch (Acts 15:3). There was also an all congregations conference in Jerusalem (Acts 12:1-5, 15:4) and another all congregations conference met at Ephesus (Acts $20: 17,28)$. Viola $(2008: 117)$ argues that since the church is the body of Christ in a given 
location, a local church must include different team leaders of Christ's body at a particular place. The church must also accept "other members" as a team from different ethnic identity "just as Christ accepted us" (Romans 15:7).

From the aforesaid it is evident that the principle of ecumenical ecclesiastical connectionalism in the church promotes accountability, dependency, and mutual submission among congregations (Brand \& Norman, 2004:112). Calvin affirms this inclusive doctrine of church polity by citing the two great ecclesiological maxims of Cyprian of Carthage: "You cannot have God as your Father unless you have the church as your mother of all." And "Outside the church there is no hope, or remission of sins nor any salvation" (Calvin, 1536). Consequently, the principle of ecumenical ecclesiastical connectionism characterized the New Testament Church.

\section{Summary and Conclusion}

This study investigated historical and Scriptural sources to determine how basic principles of church government applied in the New Testament for its organization and operations. The aim of this study was to explore using a historical research approach, historical sources and the Holy Scriptures and determine how the systems of church government developed. The study also sought to define church government and reconstruct a relevant church polity model for the contemporary church in Reformed Church perspectives. The study established that influences from the Graeco - Roman and the Jewish Government systems played a major role in the formulation of principles of church government in the New Testament Church (Dunn, 1977:236-237, Smith, 1976:15-16). The New Testament Church followed basic elements of pluralistic systems of government from Graeco- Roman approaches as well as from Judaism in the first century (Banks, 1993:131ff, Spijker, 1996:424). In the New Testament there was no set pattern for selection and appointment of church officers although some scholars offer a varied approach (See Nicolaides, 2006).

The study also analysed the system of government for the supreme reign of Christ in the New Testament Church. Christ is the Head of the church and source of all its authority. Christ supremely reigns differently in every detail of the church and in all respects from earthly kings (Nicolaides, 2010). All believers in Christ are unconditionally bound to obey the Word of the King. As Christ is the only sovereign Ruler of the church, the Ekklesia, His Word is the only word that is law in the absolute sense. God's people are His Laos,

The use of the word 'Laos' thus denotes God's chosen people, which are distinct from the denotation of ethne, which refers to those nations who inhabit his creation (Pancaro 1969). The people of Israel were called exclusively, and especially, by God: 'and the Lord thy God chose thee to be to him a peculiar people beyond all nations that are upon the face of the earth' '(kai se proeileto Kyrios o Theos sou einai auto Laon periousion para panta to ethne, osa epi prosopou tes ges)'... Christ is the head and the body, with the church being the Laos tou Theou. The 'people of God' are the guardians of all truth, including Christian doctrine. The guardian of religion is the very body of the church, which consists of the people (Laos) themselves (Nicolaides, 2010).

The study reflected the principle of servant- leadership in the church. The nature of servantleadership that Christ taught was that he came not to be served but to serve and give his life as a ransom for many people (Mark 10:45). In Christ's Kingdom, service is the way to go ahead to greatness. In the church, leaders must be humble enough to follow the example of Jesus Christ. Leaders are therefore esteemed, not because of their office but because of their work and role-modelling of good behaviour as an ethical norm (Hunter, 1950:304ff; Nicolaides, 2017.). Leadership and ministry must be "gift based" in the church (Janssen, 2006:200).

The study also established that the system of church government for ecumenical ecclesiastical connectionism characterized in the New Testament Church (Brand \& Norman, 2004:112-113). 
Viola (2008:129) holds that during the New Testament world, local churches were completely unified in the apostolic teaching and practice. They held that the church is one under 'One Head Jesus Christ'. All believers in the New Testament Church in a specific location lived as members of one organized family under the leadership of the 'office' of an elder and deacon. As a result, the early church began rapidly expanding and brought together more people of diverse cultures which was both a huge challenge and a gracious blessing (Acts 8:1-39, 13:1, 18:22, Rom 16:1).

The study established that influences from Graeco-Roman and Jewish systems of government impacted strongly in the adoption of the principle of plurality of elders to exercise authority in the New Testament Church. From Scripture, it was conceived that the person's task of leadership was through God's gracious calling to service - thus someone who had church leadership as ministry and was a member of the ekklesia and laos tou theou. Elders had decision making authority with the apostles, and these decisions serve the authority of Christ by leading and binding (Acts 15:2 - 16:4). 1 Timothy 3:2 and Titus 1:7-9 use the image of the guardian as the manager of God's household, and God is the kurios (boss of the house) with the episkopoi who manages the house with the mandate from the house boss (Rensburg, 2009:445f, Gelder, 2000:178). Christ does not rule the church by force, but subjectively by His Holy Spirit, the Paraclete (Comforter)which is operative in the church, and serves objectively by the Word of God as the standard of authority.

The basic responsibility for the state of the congregation rests on the "elder", even to such a degree that in Reformed Church political definitions the existence of a congregation depends on whether there are any elders present at all. A congregation can be without an episkopos and it would be constituted as a temporary shortcoming that has to be addressed quickly. A congregation can also be without deacons, and that would also be viewed as a temporary shortcoming that has to be addressed quickly. But a congregation without presbyters (elders) cannot exist (Momberg, 2009:458). The office of elder as instituted by Christ who deemed it necessary in the church is a foundational point of departure for dealing with the matters in church polity discourses (Momberg, 2009:458). The authority of the church resides primarily in the church courts such as the session of the local church, with its presbyters and general assembly who possess ecclesiastical authority granted to them by several local churches (Brand \& Norman, 2004:124-125).

In conclusion, the study established that Christ endowed ordinary members and officers of his church with authority, and many received additional authority as is required for the performance of their respective duties. Christ has provided for the specific exercise of authority by representative organs that are set apart for the maintenance of doctrine, worship and discipline. But while it is true that Christ exercises His authority in the church through the officers, this is not to be understood in the sense that He transfers His authority to His servants. He Himself rules the church through all ages, but in doing this, He uses the appointed officers of the church as His organ. They have no absolute or independent authority as such, but only a representative authority to act and to an extent ministerial power (Berkhof, 1969:583).

According to the Reformed Church perspective, legitimate church polity must be characterized on the conviction of the Sovereignty of God, Christ as Head and Ruler and must be fundamental to understand the context of the New Testament Church (Koffeman \& Smit, 2014:40). The Scriptures never refer to any human being as a "head of the church" as claimed by the Roman Catholic Church or Episcopal Church view. This title exclusively belongs to Jesus Christ alone. He is the only Head of each local assembly. The church has no head on its own (Viola, 2008: 295). In the Reformed tradition, there is no such a thing as hierarchical and ecclesiastical power. A notion of personal hierarchy is thus intentionally structurally avoided (Janssen, 2000:15f). 
From the Reformed Church perspective, church polity must be concerned with the proclamation of the gospel of Jesus Christ, the administration of sacraments and the exercise of discipline - thus the administration of the keys of the kingdom of God (Van't Spikier, 1993:317, 1996:192ff). Church polity must lead to a system of church government which provides the channel for the true sound doctrine through which the church can be built up. In light of the Word of God, church polity should determine the fundamental principles of justice, order and method of government in the church. Gelder (2000:177-78) holds that while specific governing forms of the church are contextually shaped, they are not arbitrary. They must be carefully considered in light of biblical foundations and historical developments of Reformed traditional theology. Governing forms locate God's power and authority within church life through various leadership positions and decision - making structures. The New Testament Church adopted the system of exercising authority through offices of elders and courts of the church in obedience to the Word of God and through the illumination of the Holy Spirit. Leaders in the church must have a mature Christian character (Gelder, 2000:181). Anyone who is going to be a leader in the church must demonstrate maturity in exercising the 'fruits of the Spirit' (Galatians 5:22-23). Elders were the representatives of the people, they formed a part of all ecclesiastical assemblies, and thus partake in all authoritative acts, equally with the teaching elders and through which, by a series of judicatories, rising one above another, each individual church is under the watch and care of its appropriate judicatory and the whole body, by a system of review and control, is bound together as one homogeneous community (Hall et al., 1994:76). There was and is no such a thing as hierarchical ecclesiastical influence and power.

The contemporary church must always take the responsibility to adopt policies which will reorganize the structures which will meets the needs of the various members and foster greater health and growth within the life of church. The contemporary church must recover the lost system of church government based on the principles of the New Testament Church; where church polity rested on spiritual principles expressed in different ways depending upon the size of the church, cultures, and gifted men present. This is therefore, an approach on how to redefine, analyse and reconstruct the church government model for the contemporary church in the Reformed church perspective.

\section{References}

Banks, R. (1993). Church Order and Government in Dictionary of Paul and His Letter. Illinois: Inter-Varsity.

Berkhof, L. (1969). Systematic Theology. London: Banner of Truth.

Brand, C. O. \& Norman, R. S. (2004). Perspectives on Church Government 5 Views. Nashville: $B$ \& $\mathrm{H}$ Publishing.

Bouwman in Vorster, J. M. (2011). An Introduction to Reformed Church Polity. Potchefstroom: Potchefstroom Theological Publications (PTP).

Bucer, M in Spijker, W. T. (1996). The Ecclesiastical Offices in the Thought of Martin Bucer. Leiden: E. J. Brill.

Burtchaell, J. T. (1992). From Synagogue to Church. Cambridge: Cambridge University.

Calvin, J. (1536). Institutes of the Christian religion. Four volumes in one digital library volume. Volume 4. Translated from the Latin by Henry Beveridge. Philadelphia: Westminster Press. Library of Christian classics 19/06/2017.

Coertzen, P. (2004). Decently and in Order: A Theological Reflection on the Order for and the Order in, the Church. Leuven: Peters. 
De Villiers, J. L \& Pelser, G. M. (1988). Guide to the New Testament 2: The New Testament Milieu. Half-way House: Orion Publishers.

De Villiers, J. L. et al. (1988). Guide to the New Testament 2: The New Testament Milieu. Halfway House: Orion Publishers.

Dunn, J. D. G. (1977). Unity and Diversity in the New Testament: An Inquiry into the Character of Earliest Christianity. Philadelphia: Trinity Press.

Du Plooy, A. le R. (1982). Reformed Church Polity: Essays and Topics. North West University: Potchefstroom: TPT.

Du Plooy, A, le R. (in Koffeman, L. J, \& Smit, J). (2014). The foundation and Relevance of Reformed Church Polity: As a Theological Science. Protestant Church Polity in Changing Contexts 2.Case Studies. Proceedings of the International Conference, Utrecht, the Netherlands 7-10 November 2011.

Du Toit, A. B. et al. (1988). Guide to the New Testament 2: The New Testament Milieu. Halfway House: Orion Publishers.

Elwell, W. A. \& Yarbrough, R. W. (1998). Encountering the New Testament: A Historical and Theological Survey. Grand Rapids: Baker Academic.

Erickson, M. J. (1998). Christian Theology. Grand Rapids: Baker Academic.

Ferguson, E. (1988). Encyclopedia of Early Christianity. New York: Garland.

Gelder, C. V. (2000). The Essence of the Church: A Community Created by the Spirit. Grand Rapids: Baker Books.

Grudem, W. (1994). Systematic Theology: An Introduction to Biblical Doctrine. Leicester: Inter - Varsity.

Haitjema, T. L. in Du Plooy, A. le R. (1982). Reformed Church Polity: Essays and Topics. North West University: Potchefstroom: TPT.

Haitjema, T. L. (in Koffeman \& Smit). (2014). The foundation and Relevance of Reformed Church Polity: as a Theological Science. Protestant Church Polity in Protestant Church Polity in Changing Contexts 2. Case Studies. International Conference: Utrecht, the Netherlands 710 November 2011.

Hall, D. W. \& Hall, J. H. (1994). Paradigms in Polity: Classic Readings in Reformed and Presbyterian Church Government. Grand Rapids: William B. Eerdmans Publishing Company.

Henderson, R. W. (1962). The Teaching Office in the Reformed Tradition: A History of the Doctoral Ministry. Philadelphia: The Westminster Press.

Hornby, A.S. et al. (2015). Ethnicity. Oxford Advanced Learner's Dictionary of Current English. Oxford: Oxford University.

Hunter, M. A. (1950). The Teaching of Calvin: A Modern Interpretation. London: James Clarke \& Company.

Janssen, A. J. (2006). Kingdom, Office and Church. A Study of A. A. van Ruler's Doctrine of Ecclesiastical Office. Grand Rapids: Eerdmans.

Janssen, A. J. (2000). Constitutional Theology: Notes on the Book of the Church Order of the Reformed Church in America. Grand Rapids: Eerdmans. 
Koffeman, L. J. (2014). Religion and State in the Netherlands- a Christian perspective. In Kuster and Setio 2014. Unpublished.

Koffeman, L. J, \& Smit, J. (2014). The foundation and Relevance of Reformed Church Polity: As a Theological Science. Protestant Church Polity in Changing Contexts 2.Case Studies. Proceedings of the International Conference, Utrecht, the Netherlands 7-10 November 2011.

McKnight, S. \& Osborne, G. R. (2004). The Face of New Testament Studies: A Survey of Recent Research. Grand Rapids: Baker Academic.

Milne, B. (1982). Know the Truth: A Handbook of Christian Belief. Leicester: Inter Varsity Press.

Momberg, H. (2009). The Office of Elder: Church Historical Indications. Report Deputies Doctrinal Matters. Report Study Group Office of the Elder (Article 92: 139): 2009 Synod of Reformed Churches of South Africa.

Nicolaides, A. (2006). The State of Celibacy and the Monastic Calling: An Orthodox Perspective, Australian eJournal of Theology, 6, 1-10. (February 2006)

Nicolaides, A. (2010). 'The Laos tou Theou - an orthodox view of the "people of God"', HTS Teologiese Studies/Theological Studies, 66(1), DOI: 10.4102/hts.v66i1.37

Nicolaides, A. (2017). Driving Corporate Social Responsibility - An Ethical Approach to Sustainability, OIDA International Journal of Sustainable Development, 10(4), 19-34.

Nicolaides, A. (2018). Mary Magdalene and Orthodoxy: Apostle, Heroine or Feminist? Pharos Journal of Theology, Volume 99.

Pearsall, J. (2002). et al. Structure. The Concise Oxford English Dictionary. Tenth Edition, Revised. Oxford: University Press.

Pelser, G. M. M et al. (1988). Guide to the New Testament 2: The New Testament Milieu. Halfway House: Orion Publishers.

Rensburg Van, F. J. (2009). Bibliological Study on the Elder in the New Testament Church: Report Deputies Doctrinal Matters: Report Study Group 4. Office of the Elder (Art 92: 139: Synod of the Reformed Churches of South Africa 2009.

Ridderbos, H. (1975). The Coming of the Kingdom. Philadelphia: The Presbyterian and Reformed.

Smit, C. J. (1996). A Governing of the Heart: Mainly seen by John Calvin. Potchefstroom: Potchefstroom Theological Publications (PTP).

Smith, M. A. (1976). The Church under Siege. Leicester: Inter-Varsity.

Spoelstra, B. in Vorster, J. M. (2011). An Introduction to Reformed Church Polity. Potchefstroom: Potchefstroom Theological Publications (PTP).

Taylor, L. R. in Cowan, S. B. (2004). Who Runs the Church? Four Views on Church Government. Grand Rapids: Zondervan.

Van Rensburg, F. J. (2009). Bibliological Study on the Elder in the New Testament Church: Report Deputies Doctrinal Matters: Report Study Group 4. Office of the Elder (Art 92: 139: Synod of the Reformed Churches of South Africa 2009. 
Viola, F. (2008). Pursuing the Dream of Organic Christianity: Reimagining Church. Colorado Springs: David C. Cook.

Vorster, J. M. (2011). An Introduction to Reformed Church Polity. Potchefstroom: Potchefstroom Theological Publications (PTP).

Wagner, P. (1976). Your Church Can Grow. California: Regal Books.

Wedderburn, A. J. M. (2004). A History of the First Christians. London: T \& T Clark. 